\title{
Association of polymorphisms in CYP19A1 and CYP3A4 genes with lower urinary tract symptoms, prostate volume, uroflow and PSA in a population-based sample
}

\author{
Richard Berges · Andrea Gsur • Elisabeth Feik · Klaus Höfner • Theodor Senge • \\ Ludger Pientka · Andreas Baierl • Martin C. Michel • Anton Ponholzer • \\ Stephan Madersbacher
}

Received: 14 August 2009 / Accepted: 23 October 2009 / Published online: 17 November 2009

(c) The Author(s) 2009. This article is published with open access at Springerlink.com

\begin{abstract}
Purpose The known importance of testosterone for the development of benign prostatic hyperplasia (BPH) prompted us to test the hypothesis whether polymorphisms of two genes (CYP19A1 and CYP3A4) involved in testosterone metabolism are associated with clinical BPH-parameters.

Methods A random sample of the population-based Herne lower urinary tract symptoms cohort was analysed. All these men underwent a detailed urological work-up. Two polymorphisms in the CYP19A1 gene [rs700518 in exon 4 (A57G); rs10046 at the $\left.3^{\prime} \mathrm{UTR}(\mathrm{C} 268 \mathrm{~T})\right]$ and one in the
\end{abstract}

R. Berges

Pan-Klinik, Cologne, Germany

A. Gsur · E. Feik

Department of Medicine I, Division Institute of Cancer Research,

Medical University of Vienna, Vienna, Austria

\section{K. Höfner}

Department of Urology, Hospital Oberhausen,

Oberhausen, Germany

T. Senge $\cdot$ L. Pientka

Department of Urology, Ruhr-University Bochum,

Bochum, Germany

\section{A. Baierl \\ Department of Statistics and Decision Support Systems, \\ University of Vienna, Vienna, Austria}

M. C. Michel

Department of Pharmacology and Pharmacotherapy,

AMC, University of Amsterdam, Amsterdam, The Netherlands

\section{A. Ponholzer $\cdot$ S. Madersbacher $(\square)$}

Department of Urology and Andrology, Donauspital,

Langobardenstrasse 122, 1220 Vienna, Austria

e-mail: stephan.madersbacher@wienkav.at
3'UTR of CYP3A4 [rs2740574 (A392G)] were determined by TaqMan assay from genomic DNA of peripheral blood. These polymorphisms were correlated to clinical and laboratory $\mathrm{BPH}-$ parameters.

Results A total of 392 men (65.4 \pm 7.0 years; $52-79$ years) were analysed. Mean International Prostate Symptom Score (IPSS; 7.5), $Q_{\max }(15.4 \mathrm{ml} / \mathrm{s})$, prostate volume $(31 \mathrm{ml})$ and prostate specific antigen (PSA) $(1.8 \mathrm{ng} / \mathrm{ml})$ indicated a typical elderly population. Both polymorphisms in the CYP19A1 gene were not correlated to age, IPSS, $Q_{\max }$, prostate volume and post-void residual volume. Serum PSA was higher in men carrying the heterozygous rs10046 genotype $(2.0 \pm 0.1 \mathrm{ng} / \mathrm{ml})$ than in those with the CC-genotype $(1.7 \pm 0.2 \mathrm{ng} / \mathrm{ml}, P=0.012)$. Men carrying one a mutated allele of the CYP3A4 gene had smaller prostates $(27.0 \pm 2.0$ vs. $32 \pm 0.8 \mathrm{ml}, P=0.02)$ and lower PSA levels $(1.6 \pm 0.3$ vs. $1.9 \pm 0.1 \mathrm{ng} / \mathrm{ml})$.

Conclusions The inconsistent associations observed herein and for other gene polymorphisms warrant further studies. In general, the data regarding the association of gene polymorphism to BPH-parameters suggest that this disease is caused by multiple rather than a single genetic variant. A rigorous patient selection based on anatomopathological and hormonal profile may possible reduce the number of confounders for future studies thus enabling a more detailed assessment of the association between genetic factors and $\mathrm{BPH}-$ parameters.

Keywords Prostate $\cdot$ Gene polymorphism $\cdot$ Marker $\cdot$ BPH

\section{Introduction}

Benign prostatic hyperplasia (BPH), benign prostatic enlargement (BPE) and benign prostatic obstruction 
(BPO) are progressive disorders that can cause lower urinary tract symptoms (LUTS) and ultimately lead to acute urinary retention (AUR) or the need for prostatic surgery [1]. Predictors for disease progression are age, symptom status, post-void residual volume, maximum flow rate $\left(Q_{\max }\right)$ and-currently most widely used-prostate volume with prostate specific antigen (PSA) as a proxy parameter [2]. Progression risk assessment is used in contemporary medical BPH management treatment algorithms [3].

Long-term treatment with $5 \alpha$-reductase inhibitors (5ARIs) results in a $50 \%$ risk reduction for AUR or the need for surgery indicating that the disease progression can be altered by medical therapy $[4,5]$. The magnitude of this effect is dependent on various parameters, such as prostate volume. The prostate cancer (PCa) prevention trial (PCPT) has also shown that long-term treatment with finsterid in healthy men without LUTS leads to a favourable outcome regarding several BPH-parameters (AUR, need for surgery, urinary tract infection) thus supporting the concept of a preventive strategy [6].

The development of LUTS in men is a multifactorial process with multiple factors involved, such as BPH, BPE, $\mathrm{BPO}$, inflammatory processes in the prostate, changes in detrusor function, alterations of the peripheral and central nervous system and-potentially-genetic factors. A genetic marker predictive for the development of BPE, BPO or LUTS would be a major improvement for preventive strategies and patient management. In contrast to clinical parameters such as prostate volume or PSA, genetic markers would allow a much earlier risk assessment with earlier and potentially more effective intervention, e.g. by 5ARIs.

Polymorphisms of genes involved in the testosterone metabolism are currently under intense evaluation as biomarkers for PCa risk [7, 8]. The CYP19A1 gene is located on chromosome 15 (15q21.1) and encodes the enzyme aromatase catalysing the irreversible conversion of androstenedione to estrone and testosterone to estradiol [8]. Aromatase is present in the gonads and in the extragonadal tissue, including the prostate and adipose tissue [8]. Aromatase mRNA and protein have both been detected in $\mathrm{BPH}$ and PCa tissue. Polymorphisms in the CYP19A1-gene showed borderline increased risks for PCA [8]. CYP3A4 is located on chromosome 7 (7q21.1) and involved in the oxidation of testosterone to $2 \beta$-, $6 \beta$ - or $15 \beta$-hydroxytestosterone, which is biologically less active than testosterone or dihydroxytestosterone [8]. A variant in the 5' untranslated region of CYP3A4 (rs2740574) has been associated with $\mathrm{PCa}$ risk in some studies and also in men with a history of $\mathrm{BPH}$ [9].

The known importance of androgens for the pathogenesis of BPH/BPE, the potential role of CYP19A1 and
CYP3A4 genes in the androgen metabolism and association of both polymorphisms to PCa risk prompted us to investigate the association of genetic polymorphisms in the CYP19A1 and CYP3A4 genes, to several clinical and laboratory $\mathrm{BPH}$-parameters in a population-based sample (Herne LUTS study). Neither of these polymorphisms has been previously tested for their association to clinical BPHparameters.

\section{Materials and methods}

The design of the Herne LUTS study has been outlined elsewhere [10]. In brief, this is a population-based study that was initiated in 1999 in the city of Herne, Germany. Of the 8,973 men on the mailing list, $60.2 \%(n=5,404)$ completed the initial questionnaire and underwent a detailed urological examination. For the current analysis all men meeting the following criteria were eligible: serum PSA $<10 \mathrm{ng} / \mathrm{ml}$, age 50-79 years and a prostate volume $<100 \mathrm{ml}$.

Of a subset of men who entered the Herne LUTS study whole blood serum samples were stored suitable for DNA extraction. This sample of 392 men entered the current study. At baseline all participants underwent a detailed clinical investigation with assessment of the following parameters: International Prostate Symptom Score (IPSS), free uroflow study, post-void residual volume (PVR), prostate volume by transrectal ultrasound (TRUS) and a serum PSA analysis. All PSA analyses were performed by the same PSA-test.

The presence of PCa was carefully excluded by digitorectal examination and serum PSA analysis. All men with a suspicious finding on digital rectal examination (DRE) and/ or serum PSA $>4.0 \mathrm{ng} / \mathrm{ml}$ underwent TRUS guided biopsy and were only included if the biopsy was negative. Serum androgen levels were not determined.

\section{Genotyping}

Genomic DNA was extracted from peripheral blood using QIAamp Blood Midi Kit (QIAgen, Hilden, Germany). The polymorphisms were determined by 5'-nuclease TaqMan assays with ABI PRISM 7500 sequence detection system. The reaction contained $20 \mathrm{ng}$ genomic DNA, TaqMan 2× PCR Master Mix, forward and reverse primers and probes for the wild-type and the mutant allele in a total volume of $10 \mu \mathrm{l}$. Universal reaction conditions were $2 \mathrm{~min}$ at $50^{\circ} \mathrm{C}, 10 \mathrm{~min}$ at $95^{\circ} \mathrm{C}, 40$ cycles with $15 \mathrm{~s}$ at $92^{\circ} \mathrm{C}$ and annealing/extension at $60^{\circ} \mathrm{C}$ for $1 \mathrm{~min}$. Allelic discrimination was carried out by measurement of fluorescence yields of the two different dyes at $60^{\circ} \mathrm{C}$. 
Table 1 Principal cohort characteristics $(n=392)$

\begin{tabular}{lrrll}
\hline & Mean & SD & Min & Max \\
\hline Age (years) & 65.4 & 7.0 & 52 & 79 \\
IPSS & 7.5 & 5.8 & 0 & 29 \\
$Q_{\max }(\mathrm{ml} / \mathrm{s})$ & 15.4 & 8.5 & 2 & 48 \\
Prostate volume (ml) & 31.1 & 12.1 & 10 & 99 \\
PSA (ng/ml) & 1.8 & 1.8 & 0.12 & 9.9 \\
\hline
\end{tabular}

Statistical analyses

Linear regression models were estimated for parameters IPSS, prostate volume, $Q_{\max }$ and PSA, respectively. Stepwise backward regression was applied to select polymorphisms that were used to generate the final model. At each step, Akaike's information criterion (AIC) was calculated to decide if the polymorphism with the smallest effect was dropped from the model. Age was included as confounder in all four models. Polymorphisms considered as regressors were rs700518, rs1004 and CYP3A. Statistical procedures were calculated by the computer software SPSS (Chicago, IL) for Windows (version 6.0.1) and Epi Info (version $6.04 \mathrm{c}$, Centers for Disease Control and Prevention, Atlanta, GA). Descriptive analyses included Student's $t$ test of means and standard deviations. Results were considered to be statistically significant when $P<0.05$; all $P$ values were checked for multiple testing according the Bonferroni method.

\section{Results}

Patient characteristics

Principal characteristics of the study population $(n=392)$ are listed in Table 1. These data suggest a typical population of elderly men generated via population-based sampling.

\section{Cyp19A1 gene polymorphism}

All polymorphisms were distributed in the Hardy-Weinberg equilibrium.

Two polymorphisms in the CYP19A1 gene [rs700518 in exon 4 (A57G); rs10046 in the 3'UTR (C286T)] were determined (Table 2). The rs700518-AA genotype was present in $96(24.5 \%)$, the heterozygotous in 194 (49.5\%) and the homozygous GG genotype in 102 men (26\%). IPSS, $Q_{\max }$, prostate volume and PSA were similar across all rs700518 genotypes (Table 2).
The rs10046 CC-genotype was present in 91 men (23.2\%), the heterozygous in $190(48.5 \%)$ and the homozygous TT-genotype in 111 men (28.3\%). IPSS, $Q_{\max }$ and prostate volume were similar across rs 10046 genotypes (Table 2). Men carrying the heterozygotous genotype had higher PSA levels $(2.0 \pm 0.1 \mathrm{ng} / \mathrm{ml})$ than those carrying the wild-type genotype $(1.7 \pm 0.2 \mathrm{ng} / \mathrm{ml}, P=0.012)$; this level of significance remained after adjustment for multiple testing. This difference, however, was lost in men carrying both mutated alleles, i.e. lacked a "gene dose-response" (Table 2).

Cyp3A4 gene polymorphism

The AA genotype was present in 360 men $(91.8 \%)$ and the heterozygous genotype (AG) in 32 men ( $8.2 \%$ ); no one had the homozygous GG genotype (Table 3 ). There was no association between the CYP3A4 gene polymorphism and IPSS and the $Q_{\max }$ (Table 3). Prostate volume was larger in men carrying the wild-type genotype $[32.1 \pm 0.8$ (range $25-87 \mathrm{ml}$ ) vs. $27.0 \pm 2.0$ (range $26-78 \mathrm{ml}$ ), $P=0.02]$. In parallel, men carrying the AA genotype had a significantly higher serum PSA $(1.9 \pm 0.1 \mathrm{ng} / \mathrm{ml})$ than those with one $\mathrm{G}$ allele $(1.6 \pm 0.3 \mathrm{ng} / \mathrm{ml}, P=0.046)$. This level of significance was lost after adjustment for multiple testing ( $\alpha$ value 0.017).

\section{Discussion}

Polymorphisms of genes involved in the androgen pathway hold promise as biomarkers for PCa, for review see [7, 8]. However, the association between androgen pathway gene polymorphisms and PCa risk is complex and characterized by contradictory results $[7,8]$. The cause of this conflict in any particular association of genotype and phenotype is difficult to identify and it can be attributable to biological, statistical and technical causes.

Relatively little is known regarding the potential role of gene polymorphisms for the development of BPH/BPE. Although cellular origins of $\mathrm{BPH} / \mathrm{BPE}$ and $\mathrm{PCa}$ are different, both diseases are under comparable endocrine and may be under similar genetic control.

Several reasons render genetic markers for BPE clinically relevant: (1) high prevalence of the disease, (2) demographic trends towards ageing in upcoming decades, (3) availability of medical therapies (5ARI) known to alter the natural history to the disease and (4) BPE is an important prognosticator for LUTS-related complications. Men with prostates $>30 \mathrm{ml}$ have a threefold increase in the risk of AUR and a fourfold increase in the risk of undergoing BPH-related treatment compared to men with smaller 
Table 2 Association between two polymorphisms in the Cyp19A1-gene and BPHparameters

\section{Numbers indicate mean + standard error of the mean \\ * $P=0.012$}

\begin{tabular}{|c|c|c|c|c|c|}
\hline \multirow[t]{2}{*}{ Parameter } & \multicolumn{4}{|l|}{ RS 700518} & \multirow[t]{2}{*}{$P$ value } \\
\hline & A/A $(n=96)$ & \multicolumn{2}{|c|}{$\mathrm{A} / \mathrm{G}(n=194)$} & $\mathrm{G} / \mathrm{G}(n=102)$ & \\
\hline IPSS & $8.0 \pm 0.6$ & \multicolumn{2}{|c|}{$7.4 \pm 0.4$} & $7.4 \pm 0.6$ & NS \\
\hline$Q_{\max }(\mathrm{ml} / \mathrm{s})$ & $15.7 \pm 0.9$ & \multicolumn{2}{|c|}{$15.3 \pm 0.6$} & $15.3 \pm 0.9$ & NS \\
\hline Prostate vol. (ml) & $31.6 \pm 1.5$ & \multicolumn{2}{|c|}{$31.3 \pm 0.9$} & $31.4 \pm 1.7$ & NS \\
\hline PSA (ng/ml) & $1.7 \pm 0.2$ & \multicolumn{2}{|c|}{$2.0 \pm 0.1$} & $1.9 \pm 0.2$ & NS \\
\hline \multirow[t]{2}{*}{ Parameter } & \multicolumn{3}{|l|}{ RS 10046} & \multirow[t]{2}{*}{$P$ value } & \\
\hline & $\mathrm{C} / \mathrm{C}(n=91)$ & $\mathrm{C} / \mathrm{T}(n=190)$ & $\mathrm{T} / \mathrm{T}(n=111)$ & & \\
\hline IPSS & $8.0 \pm 0.07$ & $7.5 \pm 0.4$ & $7.2 \pm 0.6$ & NS & \\
\hline$Q_{\max }(\mathrm{ml} / \mathrm{s})$ & $15.7 \pm 0.9$ & $15.3 \pm 0.6$ & $15.4 \pm 0.9$ & NS & \\
\hline Prostate vol. (ml) & $31.6 \pm 1.6$ & $31.4 \pm 1.0$ & $31.3 \pm 1.5$ & NS & \\
\hline PSA (ng/ml) & $1.7 \pm 0.2$ & $2.0 \pm 0.1^{*}$ & $1.8 \pm 0.2$ & $\begin{array}{l}\text { CC vers } \\
\text { versus }\end{array}$ & $\begin{array}{l}0.012 \mathrm{CC} \\
\mathrm{S}\end{array}$ \\
\hline
\end{tabular}

Table 3 Association between a CYP3A4 gene polymorphism and BPH-parameters

\begin{tabular}{lccl}
\hline Parameter & $\mathrm{A} / \mathrm{A}(n=360)$ & $\mathrm{A} / \mathrm{G}(n=32)$ & $P$ value \\
\hline IPSS & $7.6 \pm 0.3$ & $6.6 \pm 0.9$ & $\mathrm{NS}$ \\
$Q_{\max }(\mathrm{ml} / \mathrm{s})$ & $15.4 \pm 0.5$ & $15.9 \pm 1.5$ & $\mathrm{NS}$ \\
Prostate vol. $(\mathrm{ml})$ & $32 \pm 0.8$ & $27 \pm 2.0$ & 0.02 \\
PSA $(\mathrm{ng} / \mathrm{ml})$ & $1.9 \pm 0.1$ & $1.6 \pm 0.3$ & 0.046 \\
\hline
\end{tabular}

Numbers indicate mean + standard error of the mean

prostates $[1,2]$. In addition larger prostates have a higher mean annual growth rate than smaller ones $[1,2]$.

Our study has two strengths: first, we have investigated a population-based, representative sample of elderly men, hence our cohort is not biased by referral patterns; secondly, all men in this study underwent a detailed urological investigation with exclusion of $\mathrm{PCa}$. Although it well established that around $20 \%$ of men have PCa in the $<4.0 \mathrm{ng} / \mathrm{ml}$ PSA-range based on the PCPT, the cut-off used herein $(4.0 \mathrm{ng} / \mathrm{ml})$ is clinically established. It is unrealistic to propose routine prostate biopsies in a population-based sample. Population-based samples, which are not carefully screened with this respect, carry the risk of being contaminated with PCa cases. A limitation is the rather small sample size; the down-side of using a population-based cohort is that the number of men with severe LUTS and significantly impaired flow rates is limited.

This is the first study that has investigated the association of polymorphisms within CYP19A1 and CYP3A4 genes to BPH-parameters. The CYP19A1 gene on 15q21.1 codes for aromatase that converts $\mathrm{C} 19$ androgens into aromatic $\mathrm{C} 18$ oestrogenic steroids [8]. Hence, up-regulation of this enzyme may lead to an increase in oestrogen production. The oestrogen-dominant status in men after middle age has been implicated in the induction and progression of
BPH [11]. The recent data suggest that aromatase expression in prostatic stromal cells is induced by prostaglandin $\mathrm{E}$ vis a paracrine mechanism [11]. However, functional tests in the CYP19A1 gene showed no significant changes in protein activity or level compared with the WT enzyme after transient expression in COS-1 cells [8]. Studies correlating several polymorphisms in the CYP19A1 gene to $\mathrm{PCa}$ yielded conflicting results with the majority being negative $[7,8]$. This is in line with the current study: the rs 700518 polymorphisms showed to correlation to clinical BPHparameters, the rs10046 revealed a weak correlation to PSA. While the latter remained significant after adjustment for multiple testing, it is noteworthy that there was no "gene dose-response", i.e. that homozygous TT carriers had values intermediate those of CC and CT carriers. This lack of a dose-response effect is difficult to explain and could be also due to inter- and intraindividual PSA variations. It is worth to note that the differences observed were small being in the range of these PSA variations.

Moreover, the PSA findings were not mirrored by those on prostate volume although it is generally assumed that PSA is a good proxy parameter for prostate volume.

Human CYP3A4 is the major CYP enzyme for testosterone deactivation $[7,8]$. CYP3A4 has also been shown to be involved in the regulation of cell proliferation and differentiation in prostate cells. A G $>$ A mutation located in the P450NF (nifedipine oxidase) specific element has been identified that disrupts a transcriptional regulatory element located in the $5^{\prime}$ regulatory region of CYP3A4 [8]. The reported frequency of this alteration shows clear ethnic/ geographic differences, reflecting the PCa rate, which highest in African-American men, intermediate in Caucasian men and lowest in Asian men [8]. Association with higher clinical stage and grade has been reported, although contradictory reports also exist [8]. The current analysis revealed 
no statistically association (after adjustment for multiple testing) of a CYP3A4-polymorphism to clinical BPHparameters.

Several other polymorphisms in the androgen pathway have been correlated to clinical BPH-parameters. Four studies have determined the association of the number of CAG-repeats within the androgen receptor (AR) to prostate volume [12-15]. Three studies, including a previous one from our group analysing a typical BPH-population (men referred for TURP), were negative [12-15]. Giovannucci et al. [16] reported on an association of the number of CAG-repeats within the AR to prostate volume and risk for prostate surgery.

Four studies addressed the potential role a polymorphism within the 17 hydroxylase (CYP17) gene, one of the key enzymes in testosterone biosynthesis to several BPHparameters [17-20]. While two studies observed no association to hormone levels, our group observed a lower stroma/epithelial cell ratio in individuals carrying the mutated allele [17, 18]. In a Turkish cohort, Gunes et al. [19] observed an association between this polymorphism and BPH. By analysing a population-based Chinese cohort, Madigan et al. [20] failed to identify a clear association between CYP17 polymorphism and BPH-parameters.

The potential role of polymorphisms within the $5 \alpha$ reductase gene (SRD5A2) in the development of BPH/BPE has also been addressed [13, 21, 22]. An association to serum testosterone levels has been observed in both studies analysing the SRD5A2 V89L polymorphism; larger prostates and higher PSA levels were correlated to the SRD5A2 A49T genotype [13]. Salam et al. [22] reported on a nonsignificant association between the SRD5A2 V89L polymorphism and $\mathrm{BPH}$, yet noticed a significant association for Hispanics.

In conclusion, all these studies-including the current one-yielded conflicting data which is in part due to different study designs (cross-sectional, longitudinal), different study populations (surgical cases, outpatients, populationbased cohorts, screening populations) and BPH-definitions (prostate volume, $Q_{\max }$, need for surgery). Many human traits and their underlying polymorphic genes show independent patterns of racial, ethnic and geographic variation. Understanding the importance of polymorphisms in the androgen pathway genes still requires more studies. A predisposition caused by a combination of genetic variants, of which each carries a small relative risk, may be of much greater significance. Hence, this understanding can only emerge if research extends beyond single gene studies to encompass gene-gene and gene-environment interaction studies. The inconsistent associations observed herein warrant further studies. In general, the data regarding the association of gene polymorphism to LUTS, prostate volume, uroflowmetry and PSA suggest that this disease is caused by multiple rather than a single genetic variant. If this is true, it becomes unlikely that any single gene polymorphisms will exhibit a strong enough correlation with BPHparameters and/or progression risk to be clinically useful.

Conflict of interest statement There is no conflict of interest.

Open Access This article is distributed under the terms of the Creative Commons Attribution Noncommercial License which permits any noncommercial use, distribution, and reproduction in any medium, provided the original author(s) and source are credited.

\section{References}

1. Emberton M (2003) The hallmarks of BPH progression and risk factors. Eur Urol 22(suppl 8):2-7

2. Roehborn CG (2008) BPH progression: concept and key learnings from MTOPS, ALTESS, COMBAT, and ALF-ONE. BJU Int 101(suppl 3):17-21

3. Madersbacher S, Alivizatos G, Nordling J, Sanz CR, Emberton M, de la Rosette JJMCH (2004) EAU 2004 guidelines on assessment, therapy and follow-up of men with lower urinary tract symptoms suggestive of benign prostatic obstruction (BPH guidelines). Eur Urol 46:547-554

4. McConnell JD, Bruskewitz R, Walsh P (1998) The effect of finasteride on the risk of acute urinary retention and the need for surgical treatment among men with benign prostatic hyperplasia. Finasteride Long-Term Efficacy and Safety Study Group. N Engl J Med 338:557-563

5. Debruyne F, Barkin J, van Erps P, Reis M, Tammela TLJ, Roehborn C, on behalf of the ARIA3001, ARIA3002 and ARIB3003 Study Investigators (2004) Efficacy and safety of longterm treatment with the dual $5 \alpha$-reductase inhibitor dutasteride in men with symptomatic benign prostatic hyperplasia. Eur Urol 46:488-495

6. Thompson IM, Goodman PJ, Tangen CM et al (2003) The influence of finasteride on the development of prostate cancer. N Engl J Med 349:215-224

7. Gsur A, Feik E, Madersbacher S (2004) Genetic polymorphisms and prostate cancer risk. World J Urol 21:414-423

8. Mononen N, Schleutker J (2009) Polymorphisms in genes involved in androgen pathways as risk factors for prostate cancer. J Urol 181:1541-1549

9. Tayeb MT, Clark C, Sharp L et al (2002) CYP3A4 promoter variant is associated with prostate cancer risk in men with benign prostate hyperplasia. Oncol Rep 9:653-655

10. Berges R (2008) Epidemiology of benign prostatic syndrome: associated risks and management data in German men over age 50. Urologe A 47:141-148

11. Wu Q, Zhou Y, Chen L et al (2007) Benign prostatic hyperplasia $(\mathrm{BPH})$ epithelial cell line BPH-1 induces aromatase expression in prostatic stromal cells via prostaglandin E2. J Endocrinol 195:89-94

12. Bousema JT, Bussemakers MJG, van Houwelingen KP et al (2000) Polymorphisms in the vitamin D receptor gene and the androgen receptor gene and the risk of benign prostatic hyperplasia. Eur Urol 37:234-238

13. Schatzl G, Madersbacher S, Gsur A et al (2002) Association of polymorphisms within androgen receptor-, $5 \alpha$-reductase- and PSA-genes with prostate volume, clinical parameters and endocrine status in elderly men. Prostate 52:130-138

14. Mitsumori K, Terai A, Oka H et al (1999) Androgen receptor CAG repeat length polymorphism in benign prostatic hyperplasia (BPH): correlation with adenoma growth. Prostate 41:253-257 
15. Shibata A, Stamey TA, McNeal JE, Cheng I, Peehl DM (2001) Genetic polymorphisms in the androgen receptor and type II $5 \alpha$-reductase genes in prostate enlargement. J Urol 166:1560-1564

16. Giovannucci E, Platz EA, Stampfer MJ et al (1999) The CAG repeat within the androgen receptor gene and benign prostatic hyperplasia. Urology 53:121-125

17. Schatzl G, Gsur A, Bernhofer G et al (2001) Association of vitamin $\mathrm{D}$ receptor and 17 hydroxylase gene polymorphisms with benign prostatic hyperplasia and benign prostatic enlargement. Urology 57:567-572

18. Allen NE, Forrest MS, Key TJ (2001) The association between polymorphisms in the CYP17 and 5alpha-reductase (SRD5A2) genes and serum androgen concentrations in men. Cancer Epidemiol Biomarkers Prev 10:185-189

19. Gunes S, Bagci H, Sarikaya S, Bilen CY, Kara N (2007) Prostatespecific antigen and 17-hydroxylase polymorphic genotypes in patients with prostate cancer and benign prostatic hyperplasia. DNA Cell Biol 26:873-878

20. Madigan MP, Gao YT, Deng J et al (2003) Cyp17 polymorphisms in relation to risks of prostate cancer and benign prostatic hyperplasia: a population-based study in China. Int J Cancer 107:271275

21. Allen NE, Forrest MS, Key TJ (2001) The association between polymorphisms in the CYP17 and 5alpha-reductase (SRD5A2) genes and serum androgen concentrations in men. Cancer Epidemiol Biomarkers Prev 10:185-189

22. Salam MT, Ursin G, Skinner EC, Dessissa T, Reichardt JK (2005) Associations between polymorphisms in the steroid 5-alpha reductase type II (SRD5A2) gene and benign prostatic hyperplasia and prostate cancer. Urol Oncol 23:246-253 